Quim. Nova, Vol. 36, No. 2, 220-229, 2013

\title{
CORROSION OF STEEL REINFORCED CONCRETE IN THE TROPICAL COASTAL ATMOSPHERE OF HAVANA CITY, CUBA
}

\author{
Abel Castañeda* \\ Centro Nacional de Investigaciones Científicas, P.O. Box 6412, Havana, Cuba \\ Juan José Howland \\ Escuela de Ingeniería, Instituto Politécnico, P.O. Box 19390, Havana, Cuba \\ Francisco Corvo, Tezozomoc Pérez \\ Centro de Investigación en Corrosión, Universidad Autónoma de Campeche, C.P. 24030, Campeche, México
}

Recebido em 29/3/12; aceito em 21/8/12; publicado na web em 1/2/2013

\begin{abstract}
The influence of chloride deposition rate on concrete using an atmospheric corrosion approach is rarely studied in the literature. Seven exposure sites were selected in Havana City, Cuba, for exposure of reinforced concrete samples. Two significantly different atmospheric corrosivity levels with respect to corrosion of steel reinforced concrete were observed after two years of exposure depending on atmospheric chloride deposition and w/c ratio of the concrete. Changes in corrosion current are related to changes in chloride penetration and chloride atmospheric deposition. The influence of sulphur compound deposition could also be a parameter to consider in atmospheric corrosion of steel reinforced concrete.
\end{abstract}

Keyword: concrete; steel reinforced concrete; atmospheric corrosion.

\section{INTRODUCTION}

Atmospheric corrosion aggressiveness in metals ranges from C1 to $>$ C5 according to the ISO 9223 standard in tropical coastal atmospheres. ${ }^{1,2}$ The influence of atmospheric parameters, chloride deposition and other contaminants on metals in a tropical climate have been extensively studied; $;^{3-10}$ however, in the case of reinforced concrete, chloride atmospheric deposition is not directly related to corrosion of steel reinforced concrete because the rate of chloride penetration into the concrete cover to reach steel in a reinforced concrete surface depends on the concrete's properties, particularly on its capillarity and porosity. The development of the pore structure of hydrating Portland cement systems is fundamental to the behavior of concrete exposed to a variety of aggressive environments. It influences the mass transport of ions into the material and their interaction with concrete constituents as well as the diffusion characteristics of concrete. ${ }^{11}$ Gradients of moisture content, hydrostatic pressure, stress, temperature, concentration of aggressive chemicals, and the diameter and distribution of permeable pores in the concrete, disturb the equilibrium of fluids in porous materials. Therefore, to restore the equilibrium the transference of fluids occurs. This transfer process is generally described in terms of adsorption, diffusion, absorption, and permeability. In addition, the physical state of water in the concrete pores also affects these processes.

Atmospheric corrosion aggressiveness in metals is established by weight loss or environmental parameters. ${ }^{1}$ Regarding steel reinforced concrete, the predominant type corrosion is localized corrosion which is usually called "pitting corrosion". This is not the case for metals exposed to the atmosphere, where generalized corrosion is very frequent, except in passive metals such as aluminum and others. Under this approach, an evaluation of atmospheric corrosivity regarding steel reinforced concrete should be different. In the case of coatings, time is an important factor in visually determining the deterioration caused by atmospheric aggressions; for example, the time taken to change color, the presence of corrosive products at the concrete

*e-mail: abel.castaneda@cnic.edu.cu surface, and the presence of blisters and other defects that are very important. From the corrosion point of view, concrete cover can be considered a protective composite coating deposited onto the steel. This protective coating is characterized by a relative high thickness and high porosity. In the case of paint and varnishes (coatings that are thinner and less porous than concrete), recommendations are made to use paints as protective coatings depending on the aggressiveness of the environment. ${ }^{12}$ In the case of paints, the aggressiveness of the environment is usually defined by the durability of the coating and not by the metal loss. A similar situation could be considered in the case of a concrete cover, but the durability of a concrete cover depends mainly on corrosion of steel reinforced concrete. At the same time, the adsorption of corrosive agents and water of a steel reinforced concrete surface depends on the concrete cover characteristics. Concrete properties change over a relatively wide range due to their heterogeneity representing a key factor determining chloride ion penetration. This constitutes the difficulty establishing a relative prediction of reinforced concrete durability in coastal and marine zones based on atmospheric salinity deposition. The same situation occurs in metals and coatings, for there is a wide range of coatings and metal alloys. Under such circumstances, standard reference samples could be used as patterns for atmospheric corrosivity, in the same way as it occurs on metals.

Significant corrosion of steel reinforced concrete starts when a chloride threshold is reached. After this point, the corrosive damage of the structure increases rapidly. ${ }^{13}$ Time is therefore the most important parameter to determine the influence of the environment in reaching the critical chloride content or chloride threshold on a steel reinforced concrete surface in coastal and marine zones. This period of time does not depend only on the chloride deposition in the atmosphere and other atmospheric parameters, but also on the properties of the concrete, particularly capillarity, cover thickness, etc. Under such circumstances, the corrosion and its propagation starts, and depending on the environment and the properties of the concrete cover, is relatively fast. When generalized corrosion occurs, a corrosive attack takes place across almost all the metal surface, whereas when localized corrosion occurs, other areas remain free of significant corrosion. 
Thus, corrosion current could be an index of the influence of chloride content on the corrosion of steel reinforced concrete, although it should be applied considering the type of corrosion.

Bastidas-Arteaga et al. described the influence of proximity to the sea on the probability of corrosion initiation. ${ }^{14}$ These authors used a stochastic model and the impact of distance to the sea was observed by analyzing the results spanning a 30 -year period. They observed that the probability of corrosion initiation is higher in a tropical environment than in other types of environments. Tropical environments are characterized by high values of temperature and humidity which reduce the time to onset of a corrosion process. The influence of distance to the seashore on the corrosion of steel reinforced concrete in the Yucatan Peninsula was extensively studied by Castro. ${ }^{15}$

The influence of the atmospheric environment on different types of concrete was the main study of the CYTED project DURACON, conducted throughout 11 Ibero-American countries. ${ }^{16}$ The initial results showed that in marine atmospheres, the chloride content in the environment should be considered a decisive factor when evaluating the probability of corrosion of steel reinforced concrete during the first years of study. ${ }^{17}$

Salt depositions on testing devices are due to the salt particles that impact and remain on the apparatus surfaces during the transport of marine aerosol inland.

The wet candle device is frequently used for this purpose, as part of standardized procedures for measuring the amount of chloride salts captured from the atmosphere on a given exposed area of the apparatus. ${ }^{18}$ A decreasing tendency in the total amount of chlorides that penetrate concrete structures built in coastal atmospheres has been observed as a function of distance to the shoreline under natural exposures. ${ }^{19}$ However, a direct relationship between chlorides from marine aerosol and their interaction with concrete structures has not been established. Chlorides present in the atmosphere, which can potentially be deposited onto concrete surfaces and penetrate into concrete, can be studied using different methods, including the wet candle device and dry plate device. The results can be correlated with chlorides accumulated in concrete. Recently, chloride penetration in different types of mortars was reported from a tropical country (Bangladesh). ${ }^{20} \mathrm{~A}$ relatively small atmospheric chloride deposition was determined using the wet candle device in the coastal zone, where maximums oscillated around $60 \mathrm{mg} / \mathrm{m}^{2} \mathrm{~d}$. However, in the case of Brazil, Meira proposed that the chloride deposition rate on the wet candle device can be used as an environmental indicator, which could help to increase the expected service life of concrete structures or suggest the minimum thickness of the concrete cover required to attain the necessary service life. ${ }^{21}$

In conclusion, the service life can vary by between 30 and $60 \%$ if the same concrete is in a marine atmosphere zone with 120 or with $500 \mathrm{mg} / \mathrm{m}^{2} \mathrm{~d}$, representing a more than four-fold increase in chloride deposition.

The main purpose of the present paper was to provide valuable information for maintenance, construction, designing and protection of reinforced concrete structures in the coastal region of Havana City, where significant damage in concrete structures has been observed.

\section{EXPERIMENTAL}

\section{Exposure sites}

Seven exposure sites were selected throughout Havana City, at different distances from the northern seashore, surrounded by different buildings (Table 1). Cuba is a long and narrow island located almost parallel to the Equator. Havana City is located on the northern seashore on the West side of the island. Results obtained in the first and second years of exposure are included in the present paper. The influence of existing buildings undoubtedly produces local changes in the chloride atmospheric deposition rate and in the corrosion of steel reinforced concrete. Temperature and relative humidity on the 7 sites were measured (using data loggers) every $0.5 \mathrm{~h}$ during the first year. The measuring period was September 2007- August 2008.

\section{Concrete samples}

Three samples of reinforced concrete with a water/cement ratio $0.4,0.5$ and 0.6 were prepared and placed at each atmospheric exposure site. The dimensions of the samples were $200 \times 200 \times 200 \mathrm{~mm}$. Four steel reinforcement bars $200 \mathrm{~mm}$ in length, two $20 \mathrm{~mm}$ from the concrete cover and two corresponding to $40 \mathrm{~mm}$ from the concrete cover, were placed in each reinforced concrete samples. To allow electrochemical measurements, $40 \mathrm{~mm}$ of the steel reinforcement bar protruded outside the concrete sample. The distance between the two steel reinforcement bars embedded in the concrete blocks was $10 \mathrm{~mm}$.

The reinforced concrete samples were designed to measure mainly the influence of a concrete cover ( 2 and $4 \mathrm{~cm}$ ) on the corrosion of steel reinforced concrete under atmospheric conditions. Pairs of steel reinforcement bars were located at every cover distance to use one as a working electrode and another as an auxiliary electrode. The second was used for the application of other electrochemical techniques such as polarization curves and electrochemical impedance spectroscopy in other studies. The maximum coarse aggregate size was not located between the auxiliary and the working reinforcement steel bars in the samples because its size is larger than $1 \mathrm{~cm}$, but a good electrolytic contact was established in the pair. Steel reinforcement bars in concrete were introduced after previous chemical cleaning using a hydrochloric acid solution $(36 \%)$ at room temperature under

Table 1. Relative humidity (\%), temperature, time of wetness, average chloride deposition rate, average sulphur compound deposition rate and estimated corrosivity classification according to ISO 9223 for sites located at different distances to the shoreline

\begin{tabular}{|c|c|c|c|c|c|c|c|}
\hline Stations & 1 & 2 & 3 & 4 & 5 & 6 & 7 \\
\hline Distance to shoreline (m) & $(20)$ & $(360)$ & $(615)$ & $(1500)$ & $(1600)$ & $(2678)$ & $(4500)$ \\
\hline \multicolumn{8}{|l|}{ Yearly average } \\
\hline RH $(\%)$ & 81.0 & 81.6 & 83.8 & 82.5 & 83.2 & 77.1 & 77.2 \\
\hline $\mathrm{T}\left({ }^{\circ} \mathrm{C}\right)$ & 26.1 & 26.2 & 26.6 & 28.1 & 26.5 & 28.6 & 27.9 \\
\hline TOW (h/y) & 4966 & 4789 & 4489 & 3495 & 4576 & 3782 & 3224 \\
\hline $\operatorname{ACDR}\left(\mathrm{mg} \mathrm{m}^{-2} \mathrm{~d}^{-1}\right)$ & 719.5 & 16.3 & 4.2 & 13.0 & 2.9 & 2.7 & 1.9 \\
\hline SOx DR $\left(\mathrm{mg} \mathrm{m}^{-2} \mathrm{~d}^{-1}\right)$ & 57.7 & 21.6 & 20.5 & 28.5 & 18.0 & 15.1 & 18.2 \\
\hline Corrosivity classification according to ISO 9223 & $>\mathrm{C} 5$ & $\mathrm{C} 3$ & $\mathrm{C} 3$ & $\mathrm{C} 4 *$ & $\mathrm{C} 3$ & $\mathrm{C} 3$ & $\mathrm{C} 3$ \\
\hline
\end{tabular}

* Previously determined 
Table 2. Concrete composition used

\begin{tabular}{|c|c|c|c|c|c|}
\hline \multirow{2}{*}{ Constituents } & \multicolumn{3}{|c|}{ Concrete water/cement ratio } & \multirow{2}{*}{ Fineness modulus (\%) } & \multirow{2}{*}{ Density $\left(\mathrm{g} / \mathrm{m}^{3}\right.$} \\
\hline & 0.4 & 0.5 & 0.6 & & \\
\hline Cement (kg) & 365 & 365 & 365 & 1.6 & 3.14 \\
\hline Sand $(\mathrm{kg})$ & 750 & 750 & 750 & 3.6 & 1.45 \\
\hline Coarse aggregate $(\mathrm{kg})$ & 1030 & 1030 & 1030 & - & 1.48 \\
\hline Water (L) & 148 & 186 & 222 & - & - \\
\hline Water-reducing admixture ( $\%$ of cement weight) & 1.7 & 1.2 & 1.0 & - & - \\
\hline
\end{tabular}

an extraction hood and thoroughly rinsed. The rebars were immediately dried in order to remove any possible corrosive product from the surface and maintained under similar conditions.

The aggregate combinations and their properties, the necessary water quantity, and the admixture volume for the preparation of the reinforced concrete sample are shown in Table 2. All samples were cured for 28 days by total immersion in water (curing tank).

The origin of the different aggregates was as follows: Portland cement P-350 produced in a Cuban factory, washed sand sourced from a quarry, gravel grade A (limestone) $19 \mathrm{~mm}$ also quarried, as well as super plasticizer admixture to reduce the water content in the concretes by about $20-25 \%$.

A group of concrete samples was prepared to determine their physicochemical properties, such as compressive strength, density, ultrasonic pulse velocity, capillary absorption coefficient, and effective porosity. The slump was determined by using the Abrams cone method (Table 3). ${ }^{22-26}$

Table 3. Abrams cone slump, compressive resistance, density, capillarity absorption coefficient, effective porosity and ultrasound pulse velocity of the concrete samples prepared

\begin{tabular}{lccc}
\hline \multirow{2}{*}{ Concrete properties } & \multicolumn{3}{c}{ Concrete water/cement ratio } \\
\cline { 2 - 4 } & 0.4 & 0.5 & 0.6 \\
\hline Cone slump $(\mathrm{cm})$ & 15 & 17 & 18 \\
Compression strength $f_{c k}(\mathrm{MPa})$ & 35.1 & 29.4 & 25.6 \\
Density of fresh concrete $\left(\mathrm{kg} / \mathrm{m}^{3}\right)$ & 2352 & 2342 & 2308 \\
Capillary absorption $\mathrm{K}\left(\mathrm{kg} / \mathrm{m}^{2} \mathrm{~s}^{1 / 2}\right)$ & 0.00189 & 0.00559 & 0.0126 \\
Effective porosity $\varepsilon(\%)$ & 8.05 & 13.32 & 19.65 \\
Ultrasound velocity $\mathrm{m} / \mathrm{s})$ & 4241.6 & 4082.1 & 3920.8 \\
\hline
\end{tabular}

The compressive strength was determined by using a $2000 \mathrm{kN}$ testing machine. The samples prepared for this test had a cylindrical shape (height $=30 \mathrm{~cm}$ and diameter $=15 \mathrm{~cm}$ ) and were also cured for 28 days by total immersion in water. Three values of concrete compressive strength were determined for each w/c ratio.

Ultrasonic pulse velocity can be used as a criteria of concrete homogeneity. A TIC PROCEQ model instrument was used to measure the ultrasonic pulse velocity. Transmitter and detector were placed in parallel, obtaining a direct measure of the ultrasonic pulse velocity. Two samples of concrete of the same dimension (200 x $200 \mathrm{x}$ $200 \mathrm{~mm}$ ) without reinforcement steels were evaluated for every w/c ratio. The evaluation was carried out for all the parallel faces; three per sample. The values obtained show that the concrete homogeneity was acceptable in general (Table 3).

The capillarity absorption coefficient and effective porosity were determined on the basis of the methodology established by Göran Fagerlund and according to the Cuban standard. Two cylindrical shape samples measuring $62 \mathrm{~mm}$ in diameter were extracted in samples with a w/c ratio $0.4,0.5$ and 0.6 . These specimens were cut $20 \mathrm{~mm}$ thick. Each cylinder was cut into eight pieces. For every w/c ratio, 16 small cylinders measuring $20 \mathrm{~mm}$ height were obtained. All pieces were dried in an oven at $50^{\circ} \mathrm{C}$ for $48 \mathrm{~h}$ to constant weight. The samples were covered with paraffin wax on their sides. Subsequently, the pieces were placed in desiccators under relative low humidity.

The test cylinders were placed on a layer of silica sand about $20 \mathrm{~mm}$ thick where the water level was maintained $5 \mathrm{~mm}$ over the lower surface of the cylinders. A suction process took place only at the lower surface.

After weighing, all cylinders were placed on the sand layer and later, at different times according to the testing program, were reweighed. An analytical balance ( $0.2 \mathrm{mg}$ accuracy) was used.

\section{Measurement of pollution}

The atmospheric chloride deposition rate [ACDR] was obtained using a dry plate device, consisting of a piece of dry cotton fabric 320 x $220 \mathrm{~mm}$, stretched over a wood holder, perpendicular to the wind, and exposed under a shed (Figure 1). The piece of dry cotton was changed at the end of each month at each exposure site, and stored in a polymer bag (September 2007 to August 2008). The amount of chloride deposition on the dry cotton was analytically determined by potentiometric titration with an $\mathrm{AgNO}_{3}$ solution $0.05 \mathrm{M}$. The deposition rate was then calculated. ${ }^{27}$ The sulphur compound deposition rate $[\mathrm{SOxDR}$ ] was obtained using alkaline plates $150 \times 100 \mathrm{~mm}$, also placed perpendicular to the wind (Figure 1). The piece was changed and stored in the same manner as the dry cotton fabrics. The amount of sulphur compounds was determined by the incineration of alkaline plates in a furnace at a temperature of $750{ }^{\circ} \mathrm{C} .{ }^{28}$

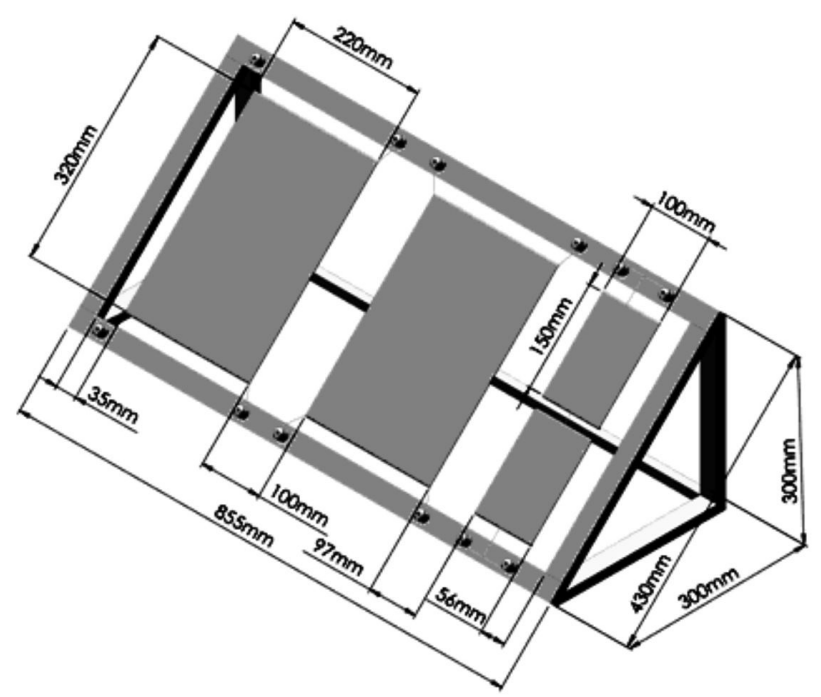

Figure 1. Wood holder used for the placement of the pollutants device 


\section{Chloride penetration}

The chloride concentration was determined using the ASTM standard. ${ }^{29}$ Chloride penetration $\left[\mathrm{Cl}^{-}\right]$was determined on the surface at $1 \mathrm{~cm}$ depth after 1 year of exposure and at 1 and $2 \mathrm{~cm}$ depth after 2 years of exposure, considering the regions where chloride penetration occurs due to capillary absorption, that is, depending on the capillarity coefficient of concrete. The influence of the atmospheric environment should be more significant in this part of the concrete cover.

Chloride at the surface was determined by scraping to a depth of $1 \mathrm{~mm}$ using a metal spatula. At 1 and $2 \mathrm{~cm}$ depths, $10 \mathrm{~g}$ amounts of concrete powder were extracted by drilling where the drill bit diameter was smaller than the coarse aggregate size.

\section{Evaluation of corrosion current}

The corrosion current was measured by using a GECOR-8 instrument. This equipment is widely used for determining potential corrosion and current corrosion measurements in diagnostic work on site. It has a circular shaped sensor in which reference electrodes, in this case copper/copper sulfate, and an auxiliary electrode are found. A wet cloth was placed between the sensor surface and the concrete cover surface in order to ensure a good electrolytic contact in the measurement system. This measurement area had remained perpendicular to the wind during the first and second years of exposure.

The steel reinforcement bars were placed in all cases with the $2 \mathrm{~cm}$ deep bar on the left and with the $4 \mathrm{~cm}$ on the right sides. The reinforcement steel protruding section of $4 \mathrm{~cm}$ was taken as the contact point with the equipment.

This zone had an adhesive tape as temporal protection against corrosion. Epoxy coating was not applied to ensure good electrolytic contact. The free area of steel reinforcement for determining the corrosion rate was $62.54 \mathrm{~cm}^{2}$. The measurements were similarly performed on site, i.e., by pressing the sensor on the surface of the reinforced concrete sample until obtaining the corrosion current values (Figure 2). The equipment uses a polarization resistance technique for this purpose.

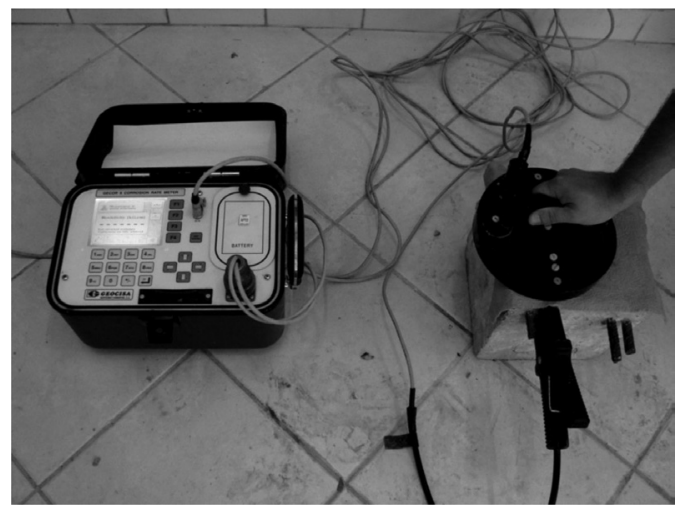

Figure 2. Measuring system to obtain the corrosion steel rate in a reinforced concrete sample

\section{Statistical treatment of data}

Regression equations and correlation coefficients were obtained using the Statgraphics software version 5.0. It is important to note that, given the complex nature of atmospheric corrosion phenomenon, it is common to use statistical treatment of data. ${ }^{30}$ Atmospheric parameters such as temperature, relative humidity, rainfall, pollutant deposition and others are not as regular and fixed as they are under laboratory conditions, changing according to atmospheric conditions, climatic season and other factors. Under these conditions, statistical treatment of data is necessary to elucidate the influence of a complex set of parameters on atmospheric corrosion of materials. It is important to take into account that the statistical treatment of data is a highly valuable tool, but should be applied taking into consideration the basis of the atmospheric corrosion phenomena.

\section{RESULTS AND DISCUSSION}

\section{Atmospheric corrosivity classification of corrosion sites}

It is important to note that Station 2, a site located $360 \mathrm{~m}$ from the shoreline, should report a significant chloride deposition rate (ACDR); but the direct arrival of marine aerosol to this site is difficult because the shed housing the reinforced concrete sample is located to the rear of a 12-story building located directly on the shoreline (Table 1). A lower-than-expected corrosivity level for the distance to the shoreline should thus be obtained.

Stations 2, 3 and 4 were closer to the shoreline of Havana Bay. In addition, the classification of atmospheric chloride deposition rate was $\mathrm{S} 1$, higher than at the other sites, except for Station 1.

Stations 5, 6 and 7 were relatively far from the shoreline, under urban influence, and should therefore have lower atmospheric corrosivity (presuming non-significant influence of the urban environment). Under these conditions, instead of a similar prediction of corrosivity to that using the ISO 9223 standard, differences in corrosivity should exist among sites located at a salinity classification S3, other sites at a distance of less than $1 \mathrm{~km}$ to the shoreline (including Station 4) with an S1 classification and those sites situated at more than $1 \mathrm{~km}$ to the shoreline (Stations 5, 6 and 7) having So classification.

According to the location of the sites, extreme atmospheric corrosivity (>C5) should be expected at the Station 1 site because it is located less than $20 \mathrm{~m}$ from Cuba's North shoreline, ${ }^{3}$ followed by Stations 2 and 3 with a lower level of corrosivity. The influence of marine aerosol should be lower at sites located at a distances further than $1 \mathrm{~km}$ to the shoreline, except for Station 4 (there is a previous report of a $\mathrm{C} 4$ atmospheric corrosivity level for this site) because it is located close to Havana Bay. ${ }^{2}$

It can be observed that the average temperature fluctuates between 26.1 and $28.6{ }^{\circ} \mathrm{C}$ (Table 1). Although changes in temperature are small, an increase in average temperature is observed at greater distances from the shoreline. These conditions could favor a slightly enhanced chloride penetration in samples near the shoreline because the condensation of moisture occurs more readily at lower temperatures.

Regarding relative humidity, average values are lower for the two sites located far from the shoreline, corresponding to higher average temperatures. Sites located closer to the shoreline showed a relative humidity average of over $80 \%$. These conditions show that the penetration of chlorides is likely to be enhanced at sites close to the shoreline because capillarity absorption of soluble chlorides should occur more readily. Besides, the chloride deposition rate is higher near the shoreline. Chloride diffusion diminishes as temperature increases, but in the nearest concrete surface Chloride penetration occurs mainly by capillarity absorption, and therefore the influence of differences in chloride diffusion should not be so significant given the small change in air temperature.

\section{Atmospheric chloride deposition rate. First year of exposure}

The determination of the atmospheric chloride deposition rate [ACDR] through a dry cotton device differs with respect to the wet candle device in that with the latter method the surface is constantly wet and is more sensitive to chloride aerosol. In the dry plate device, 
the surface of the cotton fabric absorbs water and contaminants due to its porosity, similar to the concrete's surface. The results, in general, are comparable, but the data obtained from the dry plate device are usually lower than those from the wet candle device. ${ }^{1}$ Perhaps the dry plate device could represent a better approximation for a porous material system. The classification of salinity at the Havana sites has been reached based on the atmospheric chloride deposition rate [ACDR] determined by using a dry candle device.

Changes in the ACDR of the closest site to the shoreline in Havana City are shown in Figure 3. The highest deposition rate is found during the Winter period (dry season: November to April). Changes in the ACDR of the other 6 exposure sites are shown in Figure 4. The same behavior is observed in the Winter period (dry season). Station 4 shows the highest deposition among the 6 sites. It is located 1500 $\mathrm{m}$ from the seashore, but at the same time was placed about $200 \mathrm{~m}$ from the inner shore of Havana Bay.

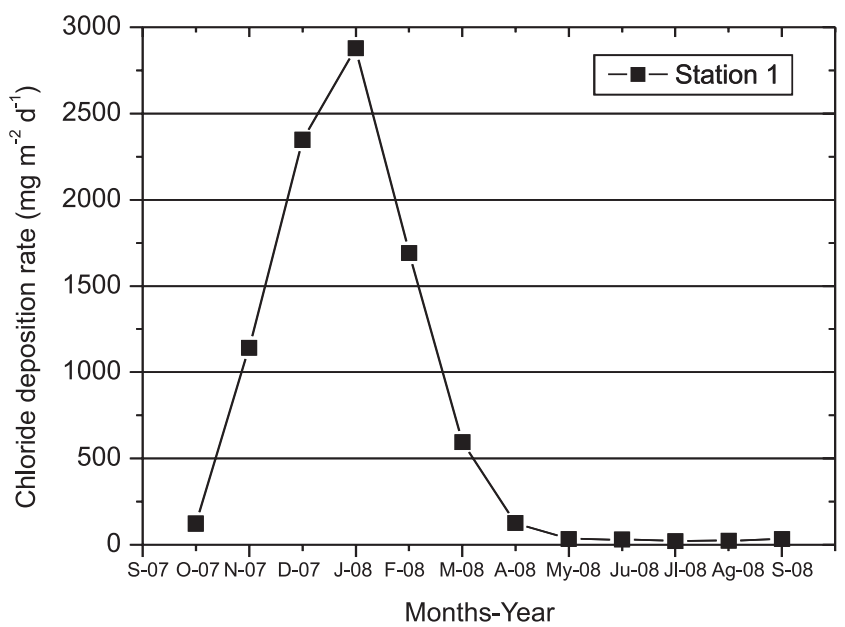

Figure 3. Monthly chloride deposition rate determined at $20 \mathrm{~m}$ from the shoreline in Havana

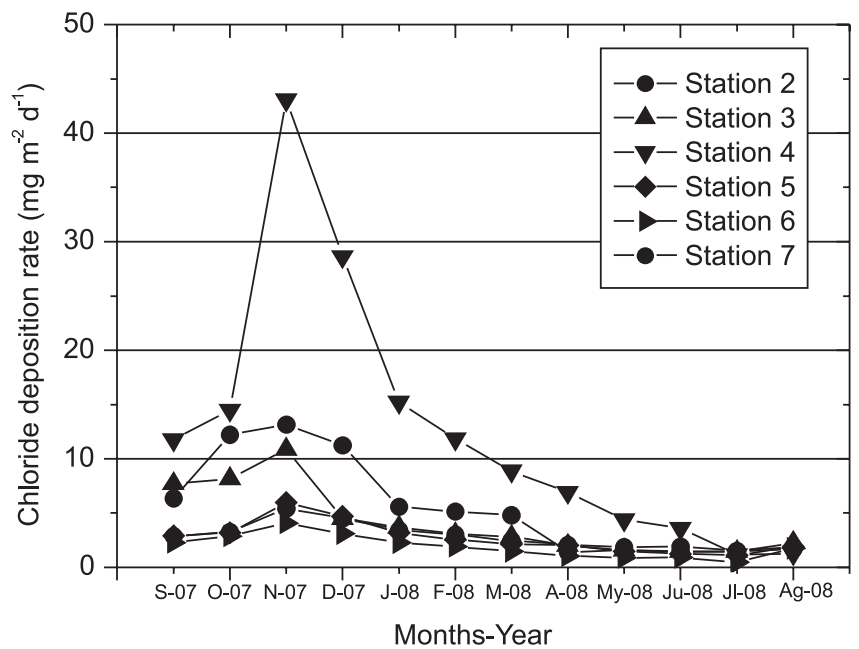

Figure 4. Monthly chloride deposition rate determined at six exposure sites located at different distances to the shoreline in Havana City

The magnitude of ACDR is extremely high at Station $1(20 \mathrm{~m}$ to the shoreline). These conditions are expected to be associated with a strong atmospheric corrosion rate at this site. ${ }^{1}$ With respect to the other 6 sites, Station 4 had a C4 atmospheric corrosivity level, Stations 2 and 3 showed an ACDR classification of S1 while the other 3 sites had So.

Some expressions such as $\left[\mathrm{ACDR}^{-}\right]=\mathrm{ad}^{-\mathrm{b}}$ to represent change in ACDR with distance to the shoreline have been proposed. ${ }^{19}$ The ACDR yearly average data determined at seven sites in Havana were processed versus the distance to the shoreline and fitted to the following exponential relationship:

$$
\begin{gathered}
{[\mathrm{ACDR}]=10170.7[\mathrm{~d}]^{-1.06}} \\
\mathrm{n}=7 \quad \mathrm{r}=-0.934 \quad \mathrm{r}^{2}=0.872 \quad \mathrm{P}<0.01
\end{gathered}
$$

where, $d$ is the distance to the shoreline $(m)$. This implies that the same type of expression can be obtained in the case of Havana City, that is, a sharp decrease in the chloride deposition with longer distance from the seashore. It should be considered that this relationship was not obtained in flat territory, but for territory housing buildings of different sizes. Indeed, the salinity found for Stations 2 and 3 should be higher when there are no obstacles to the distribution of sea aerosol. Changes in coefficients of the above expression are probably due to environmental salinity spread through a space without obstacles.

\section{Sulfur compound deposition rate. First year of exposure}

The sulphur compound deposition rate (SOxDR) could be of natural origin or a product of man's behavior. It can be seen that the highest sulphur compound deposition rate corresponds to the exposure site located closest to the shoreline (Table 1). The main source of SOxDR in this case is likely marine aerosol. It is also important to note (Figure 5) that, akin to ACDR, the maximum SOxDR is determined for the Winter season (Nov-April).

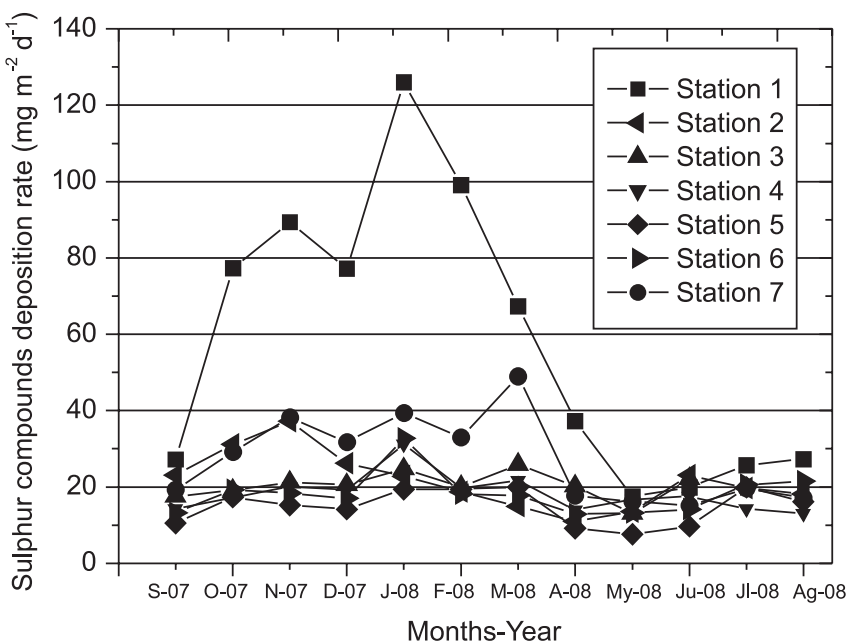

Figure 5. Sulphur compounds deposition rate determined at seven exposure sites located at different distances to the shoreline in Havana City

Station 4 had an SOxDR higher than all other Havana exposure sites, except for Station 1. The deposition rate was also higher in the Winter time; however, it could be possible that the origin of sulphur compounds may not have been due to marine aerosol alone, but also to industries and urban sources, according to the location of this site. ${ }^{31}$ It is important to note that around Havana Bay there is a significant number of industries and other possible sources of contamination.

A general pattern of behavior showing higher SOxDR in Winter time can be observed at all sites. This implies that the Sulphur compounds of natural origin are a significant part of the total Sulphur compound deposition. A similar exponential relationship to that obtained from chlorides confirms the influence of marine aerosol on SOxDR:

$$
\begin{gathered}
{[\text { SOxDR }]=95,06[d]^{-0.212}} \\
n=7 \quad r=-0.879 \quad r^{2}=0.772 \quad P<0.01
\end{gathered}
$$




\section{Chloride penetration profiles. First year of exposure}

Chloride salts are transported into concrete by a combination of capillary absorption and diffusion, with a preponderance of capillary absorption in the superficial layers, whereas wetting and drying cycles play an important role in the inner layers. ${ }^{13}$

The chloride penetration $\left(\mathrm{Cl}^{-}\right)$determined (at the concrete surface and at a depth of $1 \mathrm{~cm}$ ), depending on the distance to the shoreline, after one year of exposure is shown in Figure 6 for 3 water/cement $(\mathrm{w} / \mathrm{c})$ ratios. It can be observed that, in general, chloride concentration is lower at the surface than at a depth of $1 \mathrm{~cm}$ penetration.

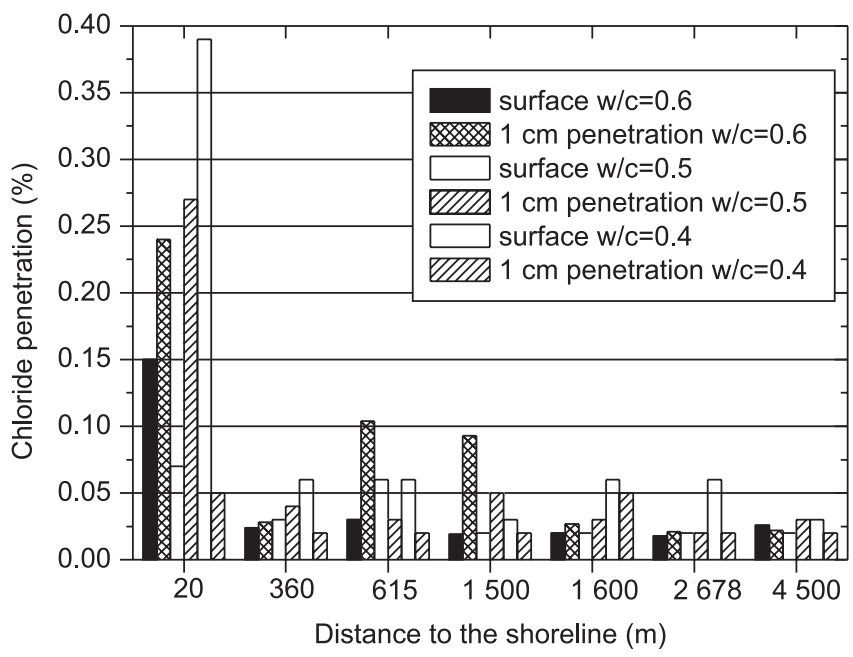

Figure 6. Chloride penetration after 1 year of exposure on the surface and at $1 \mathrm{~cm}$ depth into concrete depending on the distance to the north shoreline and $w / c$ ratio

Reinforced concrete samples were evaluated at the end of the wet period (Summer), when the rains are more intense and frequent. This situation could cause the superficial concentration to be lower than at $1 \mathrm{~cm}$ penetration depth. The highest difference between the two layers is observed at $\mathrm{w} / \mathrm{c}$ ratio of 0.6 . The effective porosity of samples (Table 3) is almost double for samples with w/c $=0.6$, compared to others with lower w/c ratios. The higher capillarity absorption coefficient and effective porosity favor the penetration of chloride through the concrete cover.

It is interesting to note that a sharp decrease in $\mathrm{Cl}^{-}$is evident between Station 1 and Station 2, while Stations 3 and 4 showed a higher chloride penetration (Figure 6). Station 2 was screened from direct arrival of marine aerosol because the site was located in a parking area to the rear of a 12-story building facing the shoreline and screening the direct arrival of marine aerosol. At the same time, Station 4 was located $1500 \mathrm{~m}$ from the shoreline, but close to Havana Bay, explaining the higher chloride concentration determined. Station 3 was located at a longer distance to the shoreline, but with fewer obstacles to stop the arrival of marine aerosol, only a group of trees; however, there is a difference between the average atmospheric ACDR and $\mathrm{Cl}^{-}$penetration at Station 2, evidencing higher ACDR and lower $\mathrm{Cl}^{-}$than Station 3. The main difference between these two exposure sites was that Station 2 was completely screened from the direct arrival of marine aerosol, which was not the case for Station 3, where the trees in front can screen part but not all of the direct marine aerosol. Station 2 reported a lower average relative humidity (81.6\%) compared to Station 3 (83.8\%). Perhaps the presence of a high humidity at Station 3 and also greater influence of winds coming from the shoreline could have led to more favorable conditions for chloride penetration, instead of a lower level of chloride deposition. It is also important to note that Station 4 (higher average RH than Station 2 and slightly higher atmospheric chloride deposition) reported a higher chloride penetration than Station 2. A possible explanation could be that lower relative humidity could create conditions for lower chloride penetration at Station 2 versus Stations 3 and 4 . A difference in sensitivity for chloride determination could have occurred between the surface of the dry plate device and the surface of the reinforced concrete samples. Small chloride particles could be absorbed by the dry plate device, but those small particles which arrive to the concrete surface could be absorbed by dust particles existing on the surface and carried by the wind. In the case of larger chloride particles, these could be absorbed by the dust existing on the surface of concrete, but remain on the surface because they absorb more water. In the above situation, it follows that for a higher relative humidity a higher chloride penetration is obtained. The existence of a higher humidity could thus facilitate chloride penetration.

Using a calculation based on Computational fluid dynamics, Cole determined that the deposition ratio on a building relative to a wet candle device is 0.08 at the rear of a building. ${ }^{32}$ Application of this calculation to Station 2 indicates that chloride deposition, if the blocking building had been absent, would have been 12.5 times higher.

A very clear difference in chloride penetration is observed between the $3 \mathrm{w} / \mathrm{c}$ ratios tested after one year of exposure. This shows that corrosion of steel reinforced concrete starts earlier in samples having higher w/c ratio and consequently, higher capillarity absorption coefficients and effective porosity. At the site where an extreme corrosion rate of carbon steel is highly probable (Station 1), due to a very high ACDR, the highest chloride penetration is reported, especially at the highest $\mathrm{w} / \mathrm{c}$ ratio.

At the other sites located less than $1 \mathrm{~km}$ from the North shoreline (including Station 4 because it was placed near Havana Bay) could be considered a second level of corrosivity. A third level of corrosivity could be attributable to those sites located more than $1 \mathrm{~km}$ from the shoreline, perhaps including Station 2, due to lower chloride penetration. A longer exposure time will be necessary to clarify the existence of a third corrosivity level.

It is important to note that a chloride threshold, considered $0.4 \%$ of cement weight, had not been reached in any of the reinforced concrete samples after one year of exposure (based on determinations at a penetration depth of $1 \mathrm{~cm}$ ).

A multilinear regression analysis carried out between the average chloride penetration $\left(\mathrm{Cl}^{-}(\%)\right)$ at $1 \mathrm{~cm}$ depth versus average ACDR determined by a dry plate device and water/cement ratio gave the following results:

Penetration of chloride at $1 \mathrm{~cm}$ depth (1 year):

$$
\begin{gathered}
{\left[\mathrm{Cl}^{-}\right]=-0.1+0.0001[\mathrm{ACDR}]+0.27[\mathrm{w} / \mathrm{c}]} \\
\mathrm{r}^{2}=55.07 \quad \mathrm{P}<0.01
\end{gathered}
$$

where $\mathrm{w} / \mathrm{c}$ is the water/cement ratio. This shows that w/c ratio and atmospheric ACDR are two important variables determining chloride penetration at $1 \mathrm{~cm}$ depth, but less than $60 \%$ changes in chloride penetration at $1 \mathrm{~cm}$ depth are explained by the relationship obtained. A similar dependence was obtained if instead of w/c ratio, capillarity absorption coefficient was included:

$$
\begin{aligned}
& \text { Penetration of chloride at } 1 \mathrm{~cm} \text { depth }(1 \text { year }) \text { : } \\
& \qquad \begin{array}{r}
{\left[\mathrm{Cl}^{-}\right]=-0.004+0.0001[\mathrm{ACDR}]+5.16[\mathrm{~K}]} \\
\mathrm{r}^{2}=56.96 \quad \mathrm{P}<0.01
\end{array}
\end{aligned}
$$

where, $\mathrm{K}$ is the capillarity absorption coefficient $\left(\mathrm{kg} / \mathrm{m}^{2} \mathrm{~s}^{1 / 2}\right)$.

In the case of effective porosity, results are as follows: 
Penetration of chloride at $1 \mathrm{~cm}$ depth (1 year):

$$
\begin{gathered}
{\left[\mathrm{Cl}^{-}\right]=-0.03+0.0001[\mathrm{ACDR}]+0.005[\varepsilon]} \\
\mathrm{r}^{2}=55.75 \quad \mathrm{P}<0.01
\end{gathered}
$$

where, $\varepsilon$ is the effective porosity (\%). The above regression equations show an almost equivalent influence of water/cement ratio, absorption coefficient, and effective porosity are obtained for chloride penetration at $1 \mathrm{~cm}$ depth after 1 year of exposure.

\section{Chloride profile after two years of exposure}

After two years of exposure, the chloride penetration at 1 and $2 \mathrm{~cm}$ depth was significantly higher at Station 1 (Figure 7). In the cases of $\mathrm{w} / \mathrm{c}=0.6$ and $\mathrm{w} / \mathrm{c}=0.5$, the chloride penetration was higher at $1 \mathrm{~cm}$ depth than at $2 \mathrm{~cm}$. Chloride penetration significantly differed at Station 1 compared to all other sites located further inland. Concerning the corrosion of steel reinforced concrete, it should be significantly higher in Station 1 compared to the other sites. The results of statistical regression between $\mathrm{Cl}^{-}$and ACDR (first year average) in concrete at 1 and $2 \mathrm{~cm}$ of depth after 2 years of exposure are shown in Table 4 . It can be noted that, except for the $\mathrm{w} / \mathrm{c}=0.5$ after one year of exposure, a good statistical fit is obtained.

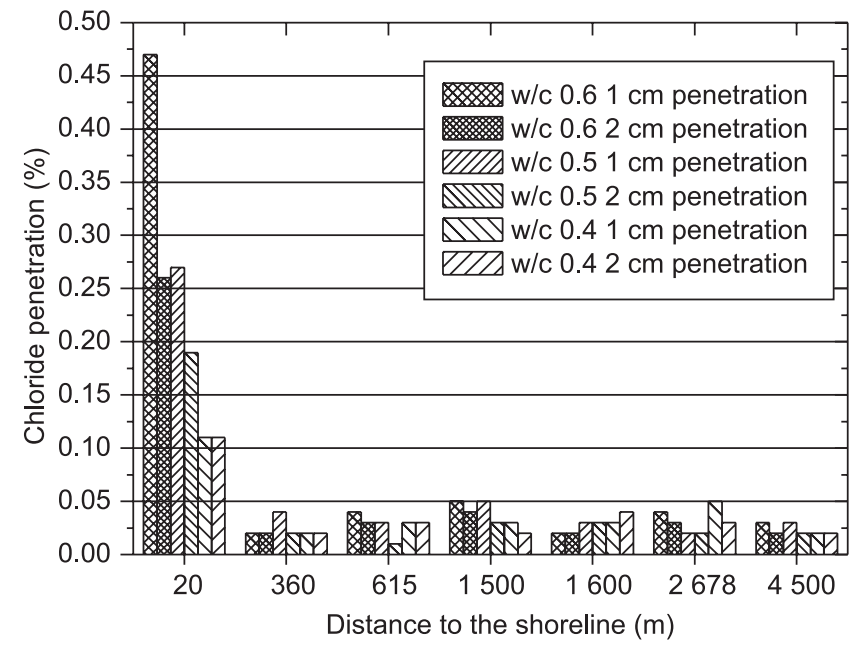

Figure 7. Chloride penetration at 1 and $2 \mathrm{~cm}$ depth after 2 years of exposure of concrete samples having different $w / c$ ratios

For all the w/c ratios at a $1 \mathrm{~cm}$ depth and 2 years of exposure:

$$
\begin{gathered}
{\left[\mathrm{Cl}^{-}\right]=-0.1+0.0004[\mathrm{ACDR}]+0.28[\mathrm{w} / \mathrm{c}]} \\
\mathrm{r}^{2}=0.76 \quad \mathrm{P}<0.01
\end{gathered}
$$

For all the w/c ratios at $2 \mathrm{~cm}$ depth and 2 years of exposure:

$$
\begin{gathered}
{\left[\mathrm{Cl}^{-}\right]=-0.03+0.00023[\mathrm{ACDR}]+0.11[\mathrm{w} / \mathrm{c}]} \\
\mathrm{r}^{2}=0.87 \quad \mathrm{P}<0.01
\end{gathered}
$$

Significant relationships were obtained between average ACDR corresponding to the first year of exposure and $\mathrm{Cl}^{-}$at 1 and $2 \mathrm{~cm}$ depth after 2 years taking into account w/c ratio. ACDR for the second year of exposure was not measured, but it is probable that the ratio of chloride deposition between sites in the second year was similar to the first year ratio. Changes are better explained by comparing two years of exposure. These results show the influence of ACDR on chloride penetration in samples exposed at Havana City sites.

\section{Corrosion current (CC)}

Regression equations obtained between corrosion current and chloride penetration after 2 years of exposure at different $\mathrm{w} / \mathrm{c}$ ratios and concrete cover thicknesses are shown in Table 5. A significant regression is obtained at w/c ratios of 0.6 and 0.5 . This could be explained by the fact that these two w/c ratios are more porous than the w/c ratio of 0.4 and the chloride penetration is higher. In the case of the latter w/c ratio, the corrosion of steel reinforced concrete should not be significant after two years of exposure. Only one statistically significant regression equation was obtained (4 cm cover). These regression equations show a direct relationship between corrosion current measured and chloride penetration in concrete.

Statistical results obtained between corrosion current determined after 1 and 2 years of exposure and the average ACDR determined during the first year of exposure at different $\mathrm{w} / \mathrm{c}$ ratios are shown in Table 6. Similar to chloride penetration, no significant regressions were obtained for the w/c ratio of 0.4 ; however, a good fit was obtained from the w/c ratio of 0.6 including the first year of exposure. An acceptable fit was also obtained from the w/c ratio of 0.5 after 2 years of exposure. This shows that ACDR is a very important parameter for determining corrosion current, and consequently, the corrosivity of the atmosphere with regard to steel reinforced concrete.

Multilinear regression analyses between corrosion current, ACDR (first year average) and the w/c ratio for one and two years, were carried out. The results are as follow:

Ic $=$ Corrosion current $\left(\mu \mathrm{A} / \mathrm{cm}^{2}\right)$.

One year of exposure $(2 \mathrm{~cm}$ cover $)$ :

$$
\begin{gathered}
{[\mathrm{Ic}]=-0.06+0.42[\mathrm{ACDR}]+0.18[\mathrm{w} / \mathrm{c}]} \\
\mathrm{r}^{2}=0.56 \quad \mathrm{P}<0.01
\end{gathered}
$$

Two years of exposure ( $2 \mathrm{~cm}$ cover $)$ :

$$
\begin{gathered}
{[\mathrm{Ic}]=-0.07+0.00009[\mathrm{ACDR}]+0.22 \mathrm{w} / \mathrm{c}} \\
\mathrm{r}^{2}=0.69 \quad \mathrm{P}<0.01
\end{gathered}
$$

Table 4. Statistical regression between chloride penetration in concrete at 1 and $2 \mathrm{~cm}$ depth after 2 years of exposure in Havana at 3 different w/c ratios and atmospheric chloride deposition rate (first year average)

\begin{tabular}{cccccc}
\hline & \multicolumn{5}{c}{ Regression equation: $\mathrm{Cl}^{-}(\%)=\mathrm{a}+\mathrm{b}$ [ACDR] $\left(\mathrm{mg} / \mathrm{m}^{2} \mathrm{~d}\right)$} \\
\hline $\begin{array}{c}\text { Chloride penetration } \\
\text { depth }(\mathrm{cm})\end{array}$ & $\mathrm{w} / \mathrm{c}$ & $\mathrm{r}$ & $\mathrm{r}^{2}(\%)$ & $\mathrm{P}$ & Regression equation \\
\hline 1 & 0.6 & 0.90 & 81.0 & (p-value) $<0.01$ & $\mathrm{Cl}^{-}=0.05+0.0003[\mathrm{ACDR}]$ \\
1 & 0.5 & 0.73 & 53.0 & (p-value) $<0.10$ & $\mathrm{Cl}^{-}=0.03+0.0005[\mathrm{ACDR}]$ \\
1 & 0.4 & 0.99 & 99.0 & (p-value) $<0.01$ & $\mathrm{Cl}^{-}=0.02+0.0003[\mathrm{ACDR}]$ \\
2 & 0.6 & 0.99 & 99.0 & (p-value) $<0.01$ & $\mathrm{Cl}^{-}=0.02+0.0003[\mathrm{ACDR}]$ \\
2 & 0.5 & 0.99 & 99.0 & (p-value) $<0.01$ & $\mathrm{Cl}^{-}=0.02+0.0002[\mathrm{ACDR}]$ \\
2 & 0.4 & 0.97 & 94.0 & (p-value) $<0.01$ & $\mathrm{Cl}^{-}=0.02+0.0001[\mathrm{ACDR}]$ \\
\hline
\end{tabular}


Table 5. Statistical regression between corrosion current of reinforced concrete and chloride penetration at 2 and $4 \mathrm{~cm}$ of depth for different w/c ratios after 2 years of exposure in Havana

\begin{tabular}{|c|c|c|c|c|c|c|}
\hline \multicolumn{7}{|c|}{ Regression equation: $\mathrm{Ic}\left(\mu \mathrm{Acm}^{-2}\right)=\mathrm{a}+\mathrm{b} \mathrm{Cl}^{-}(\%)$} \\
\hline Cover $(\mathrm{cm})$ & $\begin{array}{l}\text { Chloride penetra- } \\
\text { tion depth }(\mathrm{cm})\end{array}$ & w/c & $\mathrm{r}$ & $\mathrm{r}^{2}(\%)$ & $\mathrm{P}$ & Regression equation \\
\hline 2 & 1 & 0.6 & 0.92 & 85.0 & (p-value) $<0.01$ & $\mathrm{Ic}=0.04+0.2 \mathrm{Cl}^{-}$ \\
\hline 2 & 1 & 0.5 & 0.93 & 86.0 & (p-value) $<0.01$ & $\mathrm{Ic}=0.02+0.42 \mathrm{Cl}^{-}$ \\
\hline 2 & 1 & 0.4 & -0.13 & 2.0 & Not significant & $\mathrm{Ic}=0.02-0.03 \mathrm{Cl}^{-}$ \\
\hline 2 & 2 & 0.6 & 0.93 & 86.0 & (p-value) $<0.01$ & $\mathrm{Ic}=0.04+0.40 \mathrm{Cl}^{-}$ \\
\hline 2 & 2 & 0.5 & 0.91 & 87.0 & (p-value) $<0.01$ & $\mathrm{Ic}=0.02+0.56 \mathrm{Cl}^{-}$ \\
\hline 2 & 2 & 0.4 & -0.006 & 0.04 & Not significant & $\mathrm{Ic}=0.02+2 \mathrm{E}-06 \mathrm{Cl}$ \\
\hline 4 & 2 & 0.6 & 0.86 & 74.0 & (p-value) $<0.05$ & $\mathrm{Ic}=0.05+0.32 \mathrm{Cl}^{-}$ \\
\hline 4 & 2 & 0.5 & 0.83 & 69.0 & (p-value) $<0.05$ & $\mathrm{Ic}=0.03+0.21 \mathrm{Cl}^{-}$ \\
\hline 4 & 2 & 0.4 & 0.79 & 62.0 & (p-value) $<0.05$ & $\mathrm{Ic}=0.02+0.19 \mathrm{Cl}^{-}$ \\
\hline
\end{tabular}

Table 6. Statistical regression between corrosion current of reinforced concrete and chloride deposition rate-average in the first year of exposure at 2 and $4 \mathrm{~cm}$ of cover for different w/c ratios after 2 years of exposure in Havana

\begin{tabular}{ccccccc}
\hline \multicolumn{7}{c}{ Regression equation: Ic $\left(\mu \mathrm{A} / \mathrm{cm}^{2}\right)=\mathrm{a}+\mathrm{b}[\mathrm{ACDR}]\left(\mathrm{mg} / \mathrm{m}^{2} \mathrm{~d}\right)$} \\
\hline Cover $(\mathrm{cm})$ & $\begin{array}{c}\text { Time of exposure } \\
\text { (years) }\end{array}$ & $\mathrm{w} / \mathrm{c}$ & $\mathrm{r}$ & $\mathrm{r}^{2}(\%)$ & $\mathrm{P}$ & Regression equation \\
\hline 2 & 1 & 0.6 & 0.93 & 86.0 & (p-value) $<0.01$ & Ic $=0.02+2 \mathrm{E}-05[\mathrm{ACDR}]$ \\
2 & 1 & 0.5 & -0.25 & 6.0 & Not significant & Ic $=0.02+5 \mathrm{E}-06[\mathrm{ACDR}]$ \\
2 & 1 & 0.4 & 0.56 & 31.0 & Not significant & Ic $=0.02+5 \mathrm{E}-06[\mathrm{ACDR}]$ \\
2 & 2 & 0.6 & 0.94 & 89.0 & (p-value) $<0.01$ & Ic $=0.05+1 \mathrm{E}-04[\mathrm{ACDR}]$ \\
2 & 2 & 0.5 & 0.93 & 87.0 & (p-value) $<0.01$ & Ic $=0.03+1 \mathrm{E}-04[\mathrm{ACDR}]$ \\
2 & 2 & 0.4 & 0.07 & 0.5 & Not significant & Ic $=0.02+2 \mathrm{E}-06[\mathrm{ACDR}]$ \\
4 & 2 & 0.6 & 0.86 & 74.0 & (p-value) $<0.05$ & Ic $=0.06+1 \mathrm{E}-04[\mathrm{ACDR}]$ \\
4 & 2 & 0.5 & 0.79 & 62.0 & (p-value $)<0.05$ & Ic $=0.04+4 \mathrm{E}-05[\mathrm{ACDR}]$ \\
\hline
\end{tabular}

Two years of exposure ( $4 \mathrm{~cm}$ cover):

$$
\begin{gathered}
{[\mathrm{Ic}]=-0.05+0.00005[\mathrm{ACDR}]+0.19[\mathrm{w} / \mathrm{c}]} \\
\mathrm{r}^{2}=0.67 \quad \mathrm{P}<0.01
\end{gathered}
$$

A statistically significant probability for the influence of ACDR and w/c ratio on corrosion current determined was obtained; although the percentage explanation of results for the equation $\left(\mathrm{r}^{2}\right)$ was less than $70 \%$.

In general, corrosion current changes were according to $\mathrm{Cl}^{-}$and ACDR. This indicates that, for the Havana City coastal sites, atmospheric corrosivity affecting steel reinforced concrete after two years of exposure, depends on ACDR and w/c ratio.

Normally, the influence of SOxDR on atmospheric corrosion of reinforced steel in coastal sites is not considered. The results of statistical regressions between the corrosion current vs. ACDR and SOxDR for different w/c ratios are shown in Table 7. The inclusion of SOxDR in statistical regression increased the statistical fit for the w/c ratio of 0.6. Significant regression equations were obtained when the SOxDR was included for the other w/c ratios. Only the parameters of w/c ratio of 0.5 , one year of exposure and concrete cover $2 \mathrm{~cm}$, yielded a non-significant regression equation. This suggests that SOxDR could also influence the corrosion of steel reinforced concrete. ${ }^{33}$ Coefficient "c" represents the influence of SOxDR on corrosion current. As can be observed, except for $w / c=0.6$ in the first year, a positive sign is observed. This confirms that the influence of SOxDR increases corrosion current. A negative sign for coefficient " $b$ ", representing the influence of ACDR on corrosion current, was observed in regressions obtained for the w/c ratio of 0.4 . This result could be due to the low porosity of the reinforced concrete samples. Perhaps the influence of ACDR was not significant at the present time of exposure for this w/c ratio.

Reinforced concrete has been extensively used in all environments. Despite the effect of sulphate ions on attacking hardened concrete, which is relatively well researched in the literature, there is scant data available on the role of sulphate ions in the corrosion of steel reinforced concrete because of the lack of understanding about the role of these ions. However, the exposure of many reinforced concrete structures to sulphate-bearing soils and groundwater has brought attention to the role of sulphate ions in the corrosion of steel reinforced concrete, either when the sulphate ions are present alone or existing concurrently with chlorides. ${ }^{33}$

Sulphate ion production in the atmosphere takes place either by photo-oxidation of dimethyl sulphide or oxidations of $\mathrm{SO}_{2}$ in the atmosphere. The sulphate ions are formed from the photo-oxidation of dimethyl sulphide that is transferred from the sea to the atmosphere in the presence of sunlight. The process is referred to as gas particle conversion, and occurs at the wind - sea interface. ${ }^{34}$

When marine aerosol is transported inland into an urban zone, it incorporates gases from anthropogenic sources, mainly $\mathrm{SO}_{2}$ which becomes sulphate ions when reacting to the atmospheric ozone. These sulphate ions penetrate into reinforced concrete and react 
Table 7. Statistical regression between corrosion current of reinforced concrete, chloride deposition rate, and sulphur compounds deposition rate average in the first year of exposure at 2 and $4 \mathrm{~cm}$ cover for 1 and 2 of exposure in Havana sites

\begin{tabular}{|c|c|c|c|c|c|}
\hline \multicolumn{6}{|c|}{ Regression equation: Ic $\left(\mu \mathrm{A} / \mathrm{cm}^{2}\right)=\mathrm{a}+\mathrm{b}[\mathrm{ClDR}]\left(\mathrm{mg} / \mathrm{m}^{2} \mathrm{~d}\right)+\mathrm{c}[\mathrm{SOxDR}]\left(\mathrm{mg} / \mathrm{m}^{2} \mathrm{~d}\right)$} \\
\hline Cover $(\mathrm{cm})$ & $\begin{array}{l}\text { Time of exposure } \\
\text { (years) }\end{array}$ & $\mathrm{w} / \mathrm{c}$ & $r^{2}(\%)$ & $\mathrm{P}$ & Regression equation \\
\hline 2 & 1 & 0.6 & 91.0 & $(\mathrm{p}$-value $)<0.01$ & $\mathrm{Ic}=0.02+3 \mathrm{E}-05[\mathrm{ACDR}]-2 \mathrm{E}-04[\mathrm{SOxDR}]$ \\
\hline 2 & 1 & 0.5 & 14.0 & Not significant & - \\
\hline 2 & 1 & 0.4 & 72.0 & (p-value) $<0.10$ & $\mathrm{Ic}=0.03-3 \mathrm{E}-05[\mathrm{ACDR}]+6 \mathrm{E}-04[\mathrm{SOxDR}]$ \\
\hline 2 & 2 & 0.6 & 90.0 & (p-value) $<0.01$ & $\mathrm{Ic}=0.04+1 \mathrm{E}-04[\mathrm{ACDR}]+5 \mathrm{E}-04[\mathrm{SOxDR}]$ \\
\hline 2 & 2 & 0.5 & 87.0 & (p-value) $<0.05$ & $\mathrm{Ic}=0.02+1 \mathrm{E}-04[\mathrm{ACDR}]+6 \mathrm{E}-04[\mathrm{SOxDR}]$ \\
\hline 2 & 2 & 0.4 & 67.0 & (p-value) $<0.10$ & $\mathrm{Ic}=0.04+5 \mathrm{E}-05[\mathrm{ACDR}]+3 \mathrm{E}-05[\mathrm{SOxDR}]$ \\
\hline 4 & 2 & 0.6 & 82.0 & (p-value) $<0.05$ & $\mathrm{Ic}=0.03+7 \mathrm{E}-05[\mathrm{ACDR}]+9 \mathrm{E}-04[\mathrm{SOxDR}]$ \\
\hline 4 & 2 & 0.5 & 67.0 & (p-value) $<0.10$ & $\mathrm{Ic}=0.04+5 \mathrm{E}-05[\mathrm{ACDR}]+3 \mathrm{E}-05[\mathrm{SOxDR}]$ \\
\hline 4 & 2 & 0.4 & 74.0 & (p-valor) $<0.10$ & $\mathrm{Ic}=0.008-1 \mathrm{E}-05[\mathrm{CIDR}]+7 \mathrm{E}-04[\mathrm{SOxDR}]$ \\
\hline
\end{tabular}

with the chemical products involved in the cement hydrating process $\left(\mathrm{Ca}(\mathrm{OH})_{2}\right)$. The most frequent attack by sulphate ions is the reaction that forms plaster $\left(\mathrm{CaSO}_{4}\right)$ along with hydrated compounds that form secondary Ettringite $\left(\mathrm{C}_{6} \mathrm{AS}_{3} \mathrm{H}_{31}\right)$ which results in the expansion and cracking of cured concrete. ${ }^{31}$

These results show the influence of SOxDR which should be considered in studies of atmospheric corrosion of steel reinforced concrete; however, a more in-depth study should be carried out to confirm this finding. It should also be considered that SOxDR is mainly of natural origin, being derived from chloride aerosol. ${ }^{31}$

\section{CONCLUSIONS}

Two significantly different corrosivity levels were observed after 2 years of exposure in Havana sites as a function of atmospheric chloride deposition.

Changes in corrosion current are in accordance with changes in chloride penetration in concrete and atmospheric chloride deposition.

Preliminary results show that the influence of atmospheric sulphur compound deposition should be considered in studies of atmospheric corrosion of reinforced steel.

Chloride penetration diminishes in areas where airborne salinity does not directly reach the concrete surface due to the presence of obstacles such as buildings, trees, and such like.

\section{ACKNOWLEDGEMENTS}

The investigation carried out in Havana City has been supported by the Research Program, Branch 02 "Development and Introduction of Advanced Technologies in Concretes and Mortars Production", of the Cuban Construction Ministry.

\section{REFERENCES}

1. International Standard Organization; 9223. Corrosion of metals and alloys. Corrosivity of atmospheres. Classification, 1992.

2. Corvo, F.; Perez, T.; Dzib, L. R.; Martin, Y.; Castañeda, A.; González. E.; Perez. J.; Corros. Sci. 2008, 50, 220.

3. Corvo. F.; Betancourt, N.; Mendoza, A.; Corros. Sci. 1995, 37, 1889.

4. Morcillo, M.; Almeida, E.; Rosales, B.; Uruchurtu, J.; Marrocos, M.; Corrosión y protección de metales en las atmósferas de Iberoamérica. Parte I-Mapas de Iberoamérica de corrosividad atmosférica, Programa CYTED 1998, Editorial Gráficas Salué, S.A.: Spain, 1998.

5. Mariaca, L.; Almeida, E.; de Bosques, A.; Cabezas, A.; Álvarez, J.
F.; Joseph, G.; Marrocos, M.; Morcillo, M.; Peña, J.; Pratto, M. R.; Rivero, S.; Rosales, B.; Salas, G.; Uruchurtu-Chavarín, J.; Valencia, A. In Marine corrosion in tropical environments; Dean, S. W.; HernándezDuque, G.; Bushman, J. B., eds.; ASTM STP 1399 Publication: West Conshohocken, 2000, chap. 1.

6. Corvo, F.; Minotas, J.; Delgado, J.; Arroyave, C.; Corros. Sci. 2005, 47, 883.

7. Natesan, M.; Venkatachari, G.; Palaniswamy, N.; Corros. Sci. 2006, 48, 3584 .

8. Tran, L.; Nguyen, T.; Nishimura, R.; Tsujino, Y.; Yokoi, M.; Maeda, Y.; Corros. Sci. 2006, 48, 179.

9. Mikhailov, A. A.; Strekalov, P. V.; Panchenko, M.; Prot. Met. 2007, 43, 619.

10. Tidblad, J.; Kucera, V.; Samie, F.; Das, S, N.; Bhamornsut, C.; Chow, L.; Dawei, K.; Schollenberger, Z.; Lungu, H.; Simbi, C.; Water, Air, Soil Pollut. Focus 2007, 7, 241.

11. Beaudoin, J. J.; Jacques, M. In Handbook of analytical techniques in concrete science and technology, principles, techniques and applications; Ramachandran, V. S.; Beaudoin, J. J., eds.; Noyes publications: Park Ridge, 2001, chap. 14.

12. International Standard Organization; 12944:1998.-Paint and varnishesCorrosion protection of steel structures by protective paint systems.

13. Angst, U.; Elsener, B.; Larsen, C. K.; Vennesland, O.; Cement Concrete Res. 2009, 39, 1122.

14. Bastidas-Arteaga, E.; Chateauneuf, A.; Sanchez-Silva, M.; Bressolette, P.; Schoefs, F.; Struct. Saf. 2010, 32, 238.

15. Castro, P.; Corros. Rev. 1999, 333.

16. Trocónis de Rincon, O.; DURACON Collaboration; Build. Environ. 2006, 41, 952.

17. Trocónis de Rincón, O.; Sánchez, M.; Millano, V.; Fernández, R.; de Partidas, E. A.; Andrade, C.; Martínez, I.; Castellote, M.; Barboza, M.; Irassar, F.; Montenegro, J. C.; Vera, R.; Carvajal, A. M.; de Gutiérrez, R. M.; Maldonado, J.; Guerrero, C.; Saborio-Leiva, E.; Villalobos, A. C.; Tres-Calvo, G.; Torres-Acosta, A.; Pérez-Quiroz, J.; MartínezMadrid, M.; Almeraya-Calderón, F.; Castro-Borges, P.; Moreno, E. I.; Pérez-López, T.; Salta, M.; de Melo, A. P.; Rodríguez, G.; Pedrón, M.; Derrégibus, M.; Corros. Sci. 2007, 49, 2832.

18. American Society of Testing and Materials; Standard test method for determining atmospheric chloride deposition rate by wet candle method, ASTM G-140, Annual Book of ASTM Standard: Philadelphia, 1996.

19. Meira, G.; Andrade, C.; Padaratz, I. J.; Alonso, C.; Borba, J. C.; Atmos. Environ. 2006, 40, 5596.

20. Khandaker, M.; Hossain, A.; Said, M.; Lachemi, L.; Build. Environ. 2009, 44, 713. 
21. Meira, G.; Andrade, C.; Padaratz, I. J.; Alonso, C.; Borba, J. C.; Cem. Concr. Compos. 2007, 29, 667.

22. Cuban Standard 244:2005; Hardened concrete - Determination of compressive strength of cylindrical concrete specimens.

23. Cuban Standard ISO 6275:2005; Hardened concrete - Determination of density.

24. Cuban Standard 231:2002; Determination, interpretation and application of ultrasonic pulse velocity.

25. Cuban Standard 345:2005; Hardened concrete - Determination of the water absorption by capillarity.

26. Cuban Standard 54:1002; Testing of concrete. Part 2: Properties of fresh concrete.

27. Cuban Standard 12-01-09: 1988; Chloride content determination in the atmosphere.
28. Cuban Standard 12-01-08: 1988; Sulphur compounds determination in the atmosphere.

29. American Society of Testing and Materials; Standard Test Methods for Chemical Analysis of Hydraulic Cement, Annual Book ASTM Standards, 04.01: West Conshohocken, 2000.

30. American Society of Testing and Materials; Standard Guide for Applying Statistics to Analysis of Corrosion Date. ASTM G-16, Annual Book of ASTM Standard: Philadelphia, 2000.

31. O'Dowd, C, D.; Smith, M, H.; Consterdine, I. A.; Lowe, J. A.; Atmos. Environ. 1997, 31, 73

32. Cole, I.; Paterson, D.; J. Corros. Sci. Eng. 2004, 39, 89.

33. Saeed, O.; Build. Environ. 1998, 33, 53.

34. Piazzola, J.; Despiau, S.; Atmos. Environ. 1997, 18, 2991. 